\title{
Olgierd Górecki
}

University of Lodz

Faculty of Law and Administration

Department of Political and Legal Doctrines

e-mail: ogorecki@wpia.uni.lodz.pl

\section{Utilitarianism: Doctrinal analysis evolution of thought*}

\begin{abstract}
Utilitarianism as an innovative and original stream of ethical and political thought has enriched the philosophical discourse of the last three centuries. Utilitarian thinkers claim that maximization of pleasure correlated with minimization of pain is the correct way to create an objective catalog of rules or behaviors that result in the formation of the highest utility for a society and its individuals. From a methodological perspective, there are differences among the utilitarian philosophers on issues such as: happiness, pleasure or utility guide to diametrical disaccord on an ethical or institutional area.

The present analysis of the utilitarian thought represents some of the interesting differences in interpretation of this doctrine. However, utilitarianism does not include logical or intellectually strong arguments for the protection of an individual's rights against the interest of people at large. Thus, this doctrine during the $18^{\text {th }}$ and the $19^{\text {th }}$ centuries postulated the political egalitarianism. Nowadays, utilitarianism has lost its strong ethical position. In the past, utilitarianism was a political instrument to protect most of the people in a society from an arbitrary reigning of small elite groups. In recent times, this thought legitimizes the coercion of the majority will regardless of the fact that other smaller groups may have different political views. Such thinking allows to objectify the individual man which is only identified with instrumentality to maximization of utility.
\end{abstract}

\footnotetext{
* The article is an updated version of the paper published in Polish in the Annales. Ethics in Economic Life, 14(1), 115-126.
} 
The author analyzes the writings of Jeremy Bentham, John Stuart Mill and Herbert Spencer, and compares their doctrines with the scientific literature and forwards a basic thesis on the universal principles of utilitarianism. The author argues that the actual rules of political ethics under conditions of limitation theory of utility append the law of inviolability of the natural rights of an individual.

Keywords: utilitarianism, doctrinal analysis, evolution

JEL Classification: A13, B12

\section{Introduction}

Utilitarianism as an innovative and original ethical and socio-political trend has enriched the philosophical discourse of the last three centuries. Representatives of utilitarianism pointing to the maximization of pleasure correlated with the minimization of pain urged to establish an objective catalog of principles or behaviors, the application of which would result in the creation of the highest utility, both for the benefit of the individual and for the whole society. Differences of views among the utilitarians regarding such key concepts as, happiness, pleasure or utility have led to diametric differences on the ethical and institutional levels.

The utilitarian argument, despite its intellectual attractiveness and many interpretations does not offer a logically strong argument that would protect the individual rights if these came in conflict with the interests of the common good. Apparently, the doctrine that in the eighteenth and nineteenth centuries served the postulates of political egalitarianism has lost its strong moral position in the third millennium. A tool designed to protect much of society from arbitrary governments of an elite power group has become an instrument that legitimizes the enforcement of the will of the general even if it is contrary to the position of individuals in the minority. This leads to the moral objectification of a man who becomes only a tool to achieve maximum utility.

Referring to the views of Jeremy Bentham, John Stuart Mill and Herbert Spencer, and based on contemporary literature on the subject, I want to advance the thesis that the basic and universal assumptions of utilitarianism can remain current principles of political ethics provided that the theory of usability is limited by the addition of a rule proclaiming the inviolability of the individual's natural rights. 


\section{Jeremy Bentham (1748-1832) — the founder of utilitarianism}

Bentham, as the founder of the utilitarian trend and played a great role in shaping the British political scene. His doctrine was characterized by radicalism. In particular, he criticized the theory of natural law and the construction of a social contract. The conceptual point of his assumptions was associationism or the view that the human psyche works thanks to associations that combine sensory experience with a feeling of pleasure or pain (suffering) (Tulejski, 2004, pp. 24-27). Simplifying, since for Bentham, good was the same as pleasure, so usability has become the basic category describing all activities (Rau, 2000, p. 24). He believed that only such an action is useful, which results in pleasure. He considered this assumption a universal truth regarding the human species. This allows defining his thoughts as ethical or psychological hedonism (Copleston, 1989, p. 14). However, this was not selfish hedonism, because an individual sought to achieve happiness did not necessarily want it to be its only element. For Bentham, happiness was a direct goal of human activity.

Bentham recognized the moral equality of all people (Tulejski, 2004, pp. 45-49). From this assumption, he derived the thesis that a society was only the sum of individuals. Thus, anything that increases the sum of pleasure on a general scale and minimizes the amount of suffering is a moral behavior. Bentham described such an intellectual calculation as felicific calculus (Tulejski, 2004, pp. 41-45). He emphasized that when undertaking an activity, the effects resulting from a specific action should be carefully analyzed. The factors that describe the ensuing pleasure are: duration, purity (not accompanied by negative feelings), intensity, certainty, fecundity and extent (the feeling should include as many people as possible) (Copleston, 1989, p. 17).

However, despite making such a detailed analysis of the concept of pleasure, he has not escaped from several serious simplifications. First, he believed that in the context of the "felicific calculus" made for the whole society, happiness of every individual counted as the same. Secondly, he argued that because of the possibility of making an accurate measurement of each pleasure, all such experiences could be reduced to one common value - therefore, there was the possibility of comparing every pleasure with some other, no matter what their source. Bentham, at the expense of simplification, the categories of pleasure were irrelevant. For him, in a group of ten individuals, it was better if six people were happy consuming carrots with peas than 4 people actively involved in the political thought of past centuries. Bentham treated the notion of pleasure in quantitative and not qualitative terms, hence, the interests of all citizens accumulated to creating a general sum of happiness and pain.

When transferring these considerations to the sphere of the functioning of society and the state, we should present some of the most important conclusions resulting from the above-mentioned concept. The Bentham doctrine creates a vision of social atomism. Society is only the sum of its individuals (MacIntyre, 2000, p. 293). There is no common good that would be unrelated to the 
good of individual people (Kwaśnicki, 2000, p. 69). Therefore, within the framework of utilitarian ethics, a conduct is moral if it leads to the creation of as much pleasure as possible for the largest group of people and as little suffering or pain for as few as possible. A state, operating according to this maxim conducts rational policy providing individuals with security, guaranteeing their ownership, and ensuring the widest freedom possible (Gray, 1994, p. 43). Bentham exhorted to adapted the law to the living conditions and needs of society, without limiting the legislature's legislative or cultural tradition (Kelly, 2007, p. 47). He glorified democracy as a system in which the interests of the rulers are identical to the interests of the governed, thanks to which the postulate of freedom and equality of people is realized. Balancing the rights and obligations of citizens allows to define democracy as a useful system.

\section{John Stuart Mill (1806-1873)—individualist revision of utilitarianism}

Without a doubt, the nineteenth century was the golden age of liberalism. Among its various ideological fractions was a utilitarian group that dominated the British political reflection. The most outstanding continuator of Bentham's doctrine was John Stuart Mill, who, maintaining the rule of greatest pleasure, revised two basic assumptions of his mentor, which resulted in a significant transformation of the holistic approach to the principle of utility (cf. J. S. Mill, 1995, 2005; Ludwikowski \& Woleński, 1979; Hołówka, 1995).

First: Mill noticed that it is a fiction theorem on the equal value of all pleasures. That is why he distinguished the pleasures of the higher and lower order, respectively referring to the spiritual sphere and the physical needs of man (Kowalczyk, 1995, p. 38). In order to be able to meet the needs of a higher order, it is first necessary to take care of the basic ones. Following this line of thinking, it can be also noticed that spiritual sufferings are much more painful for a human being than the unpleasantness associated with satisfying physiological needs.

Secondly: for Mill, man's happiness was not a direct goal of human activity, but the ultimate goal of human existence (Szahaj \& Jakubowski, 2005, p. 52; Copleston, 1989, p. 32). This assumption is directly related to the two basic needs of the individual security and autonomy. Both of these needs can be substantively matched to the distribution of negative and positive freedom presented by Isaah Berlin (1969, pp. 118-172). Security corresponds to a classically liberal concept of negative liberty. For instance to say that individuals are free to do anything they wish as long their actions do not violate the same negative liberty of others (Król, 2008 , p. 86). The concept of autonomy is closer to the positive liberty, or freedom characteristic of the ethos of the ancient Greeks and Romans. Liberty, understood in this way, means freedom for self-development or participation in the public life of the state. For Mill, autonomy meant the possibility of independent decisionmaking and actions (Środa, 2003, p. 50). It related to the continuous development 
of an individual who is never shaped in his entire life. However, through autonomy an individual must constantly make choices that affect his/ her own life (Rau, 2000, pp. 75-76). Consequently, not every individual is an autonomous entity.

According to Mill, the purpose of the state is to provide individuals with security and the possibility of using autonomy. The synthesis of these two goals also indicates that the principle of the functioning of the state is the pluralism of ideological and political beliefs, religious beliefs, or other personal values, unless these are in conflict with the stated goals (Rau, 2008, pp. 30-31). The state is, therefore, useful for the individuals allowing them to achieve their ultimate happiness. Mill recognized a democracy based on the principle of representativeness as the best systemic form as it expressed the principle of the sovereignty of society and constituted a moral civic maturity (White, 2008, p. 71).

Analyzing the development of utilitarian thought, it should be noted how, along with the historical political changes (extension of electoral rights in the first half of the $19^{\text {th }}$ century), the approach to the idea of democracy has changed. Mill, being at that time one of the leading theoreticians of this system, did not treat him in an idealistic way (Król, 2008, p. 82). Realistically he noticed the dangers associated primarily with the low level of intelligence within the representatives of the parliament ("the rule of mediocrity"), and the danger of political superiority of mass movements, threatening the lack of presence of political minorities in the legislative body (Kwaśnicki, 2000, p. 82). This leads to the conclusion that Mill's utilitarian views were characterized by methodological individualism, from which he derived various postulates regarding the protection of individual rights against the will of the majority, even if utilitarian values would support it (Gray, 1994, p. 45).

\section{Herbert Spencer-instrumentalization of utilitarianism}

Herbert Spencer's doctrine was characterized by eclecticism and dynamic development of his argumentation. In his early views, we find a theory of social contract and natural law. Later, he became known as a reformer of utilitarianism. An overwhelming majority of Spencer's writing in the synthetic philosophical system compels one to treat Spencer as a social Darwinist, representative of the theory of organism, father of the founder of sociology, or ancestor of libertarianism (Boaz, 2005, p. 68).

Spencer sought a universal principle, the application of which would allow to satisfy the desires of the individual, without disturbing the freedom of others. He recalled two basic assumptions of utilitarianism - the maxim proclaiming that everything that is beneficial is at the same time right, and the principle that requires the conduct in a way that maximizes the happiness of as many people as possible. ${ }^{1}$ He claimed that the above formulae have no universal value, as they do

\footnotetext{
${ }^{1}$ The principle of greatest happiness was expressed for the first time by Francis Hutcheson in his Inquiry into the Origins of our Ideas of Beauty and Virtue (1725).
} 
not contain protection against the possibility of their incorrect implementation. It was important for him that the principle that people should use was not only universal, but also practical. The utilitarian formula for the greatest happiness cannot be a tenet of social morality, because it lacks a precise definition happiness. ${ }^{2} \mathrm{He}$ presented his own formula (more in Górecki, 2010, pp. 59-69). According to Spencer, each impact on consciousness is a feeling or a sensation. To experience these, we must be equipped with an instrument-our faculties that provide the experiences causing happiness whenever these are practiced or exercised. Every properly performed function is accompanied by a pleasant feeling. However, it should be noted, that certain sensations are interdependent with given faculties and in this way create specific pairs. Happiness is the sum of all sensations, and since the desire for something can be satisfied only by performing specific faculties, it is happiness to gratified state of all faculties (Spencer, 1851, p. 5). Therefore, every human being, having different desires and different abilities, finds himself in such a constructed definition.

Spencer has also given new meaning to the concept of "greatest happiness." He believed that this term consisted of two separate processes, which he defined as: negative and positive beneficence (Kasprzyk, 1961, p. 211). The first, the negative beneficence was the description of a state in which a completely satisfied individual was not under any influence causing a feeling of unhappiness. The positive beneficence is a process by which individuals gain an additional amount of happiness as a result of participating in the emotions of pleasure created by other people. This is a reference to the sympathy theory drawn from Adam Smith's considerations. Undoubtedly, the characteristic paradigm of Spencer, the creator of social evolutionism, is also imprinted on the presented concept. One can see in the description of the individual the impact of psychological and biological concepts that formed the basis for the concept of usability (Wroczyński, 2002, pp. 20-21).

The concept of suffering should be understood as the maladaptation of the ability to perform their level, which is associated with the lack of adaptation of the individual to specific conditions. Therefore, suffering, called by Spencer as "beneficial", contributes to the adaptation of given individuals to specific conditions, i.e. in the wider perspective generates the greatest happiness (Spencer, 2002, pp. 46, 60). On the basis of such an argument, Spencer categorically argued that people cannot be denied suffering, which serves their development - which, on the level of political postulates, reflected, among others, criticism of the social activity of the state (Szahaj \& Jakubowski, 2005, p. 138).

Such a revision of utilitarianism was not the only way of ethical argumentation for Spencer. It was only an additional justification of the supreme principle which is the "Law of Equal Freedom". This rule means that everyone has the freedom to do anything if his behavior does not violate the same freedom of another human being (Spencer, 1851, p. 103). Spencer consistently opposed any and all despotism based on political opinion, religion, race, customs, or gender

\footnotetext{
${ }^{2}$ For more on the diversity of the concept of happiness and usability within utilitarianism, cf. Sheng (1998, pp. 4-9), Häyry (1994, pp. 158-166), Quinton (1989, pp. 1-10).
} 
(Kwaśnicki, 2000, p. 101). Radically advocating for the protection of individual rights against the will of the majority, he limited the functions of the state only to justice and security (Taylor, 2000, p. 230). Certainly, one will not find in Spencer's doctrine, the utilitarian demands for realizing the will of the majority associated with achieving the greatest utility. Spencer's utilitarianism is limited by individualistic assumptions related to the doctrine of natural law (Rau, 2000, pp. 89-90). Thus, it is strictly instrumental, not an autonomous basis for ethical conduct. The utilitarianism understood in this way is not, as in the Bentham tradition, the aim of conduct, but it only becomes its criterion (Hofstadter, 1945, p. 26).

\section{Utilitarianism in a historical perspective}

Comparing the views represented by Bentham with those presented by Spencer, one can see the difference between the priorities set for both thinkers in relation to political reflection (Kasprzyk, 1967, p. 23). Simplifying, for Bentham, the supreme value was the recognition that the good of the whole society results from the maximization of the good of most citizens. From a political perspective, this is a postulate of equality of individuals and the subsequent democratization of public life (Kwaśnicki, 2000, p. 71). On the other hand, Spencer, in particular in the Man Versus the State, firmly opposed the tyranny of the majority, which imposes its will by violating the rights of the individual. Mill's thought, within such polar perception of utilitarianism, seems to be between these two radical paradigms.

When analyzing the evolution of utilitarianism, it is necessary to remember the historical connotations associated with this process. Utilitarianism in the eighteenth century and the first half of the nineteenth century was a progressive and reformist political program. He referred to political and social changes. He thus created as an ideology defending much of society against the privileged role of small elite (Copleston, 1989, p. 9). However, the argument that served this purpose lost its effectiveness when it came to the need to defend the rights of minorities against the democratic will of the majority. Similarly, it has become evident that the implementation of utilitarian principles is extremely difficult, which probably has resulted in the decline of its popularity. Apart from the long list of thinkers who negate the advantages of utilitarianism, it should be noted that he was intellectually defeated by the constructive criticism of John Rawls, contained in A Theory of Justice (White, 2008, p. 141).

\section{Methodological analysis - intellectual advantages of utilitarian construction}

Because utilitarianism has always aroused a wide response, both having numerous supporters and critics, it seems right to separate the analysis of the advantages and disadvantages of its construction. The first advantage of the utilitarian theory is its 
ethical rationalism. Its assumptions refer to rational considerations concerning the nature of man and his psychological basis of behavior. There is no reference to any metaphysical authority - it is a materialistic philosophy. In addition, utilitarianism also appears as a doctrine that recognizes the universality of human nature. The considerations concerning the happiness of the individual have the value of truth regardless of what nationality, religion, race or period of historical human life; all people have experienced pleasure and pain. Therefore, it can be stated that the analyzed thought is based on one ideologically determined goal — the promotion of happiness among all people.

The second advantage of utilitarianism is called consequentialism. This means that one may not assume or judge an action moral or immoral until its actual benefit or harm. Therefore, utilitarianism is more a criterion for assessing actions than the enumerative catalog of orders and bans. This favors an intuitive postulate to verify moral norms by conducting an empirical test of its usefulness. In search of support, the critics of utilitarianism rely on Hume's position that empirical propositions cannot be derived from task sentences (Copleston, 1989, pp. 40-41). However, this is not a valid complaint in this case, because this duty does not exclude the existence of other premises of a different nature.

The third advantage is the postulate of egalitarian treatment of people's needs. Undoubtedly, this doctrinal assumption attempting to reconcile equality with freedom can beviewed as a flaw in the utilitarian thought. However, it is a truism to say that no theory, philosophical or political or social, has ever succeeded in combining such concepts that would be accepted by everyone. Therefore, to present this issue in the most convincing and at the same time consistent with the doctrinal assumptions, it is best to talk not about the equality of all people, but the equal treatment of previous preferences of all persons (Kymlicka, 2009 , p. 63). Everyone's interests should be treated with equal care. From a moral point of view, every life is equally important. It is only right to claim that the strength of this argument serves critics of egalitarian theory. It should be remembered that it was the representatives of utilitarianism who carried out this ideological revolution, combining liberalism with the concept of democracy (Hudzik, 2002, p. 65).

\section{Methodological analysis - intellectual defects of utilitarian construction}

The doctrine of utilitarianism is not an excellent construction and devoid of certain logical imperfections. Based on the works of the three cited representatives of this trend it can be seen that it is not a homogeneous idea. However, one can bring these lines of reasoning to a common intellectual denominator to emphasize the immanent and characteristic doctrinal features of utilitarianism. The common element of all these concepts is the existence of two subjects of their considerations - a description of individual utility and a command to maximize this utility, 
assuming the moral equality of people (Kymlicka, 2009, p. 28). It should be accentuated that from the perspective of moral evaluation, the concept of utility applies only to human behaviors (for example, it can be said that a shovel is useful, which, however, does not give it a moral value) (Vardy \& Grosch, 1995, p. 68). The juxtaposition of these two principles entitles to present the conceptual weaknesses of utilitarianism.

The first weakness is the lack of a convincing definition of usability. Kymlicka, presented four separate positions (2009, pp. 28-37). The term utility can be understood as - primo: the hedonistic order is identical to experiencing pleasure, which is an end in itself; secundo: non-hedonistic psychic utility, according to which all valuable sensations or mental states are moral, regardless of the form in which they occur; tertio: satisfaction of desires, equating happiness with active action, but not recognizing the problem that the desires do not have to set our good; finally, quatro: wise desires, that is, those that are based on full information and logical judgment. All these concepts have disadvantages and advantages. Based on this analysis, it should be assumed that the stated positions are either too narrow to contain the concept of usefulness or allow one to consider utilitarian acts that conflict with one's internal intuitive morality (e.g., killing which gives pleasure to a psychopathic murderer). The issue of usability is difficult to specify. The fourth position, based on the concept of wise desires, seems to be the most thought-out, but the exclusion of the term happiness results in the inability to define these desires that undermines the pragmatism of its use.

The second problem concerns the assessment of commensurability of utility among different people. It is difficult to assess objectively what is the relationship between self and others' usability. It, therefore, concerns the application of the maximization of utility order. This amounts to an exemplary dilemma: who should be helped in an accident - a pregnant woman, or an outstanding doctor who can save more lives in the future? The problem relates to interpersonal relations and making choices, the consequences of which go beyond the person making the decision. In the general public it would require the existence of the attribute of omnipotence in reading the profits and losses of each member of the community. Only then can the policy pursued could implement rationally calculated utility.

The third disadvantage of a utilitarian construction concerns the deficit of goods necessary to satisfy needs, or, with the existence of conflicting needs between individuals. That the specified amount of utility is identical in the general account, it is not important who benefits. Therefore, no unit takes a privileged position, and all decisions are made impartially. Following this line of reasoning, it turns out that a man whose needs stand in the way of meeting the needs of the whole will act morally when acting against his individual interest. Such morality leads to the creation of a specific alienation of the human being in relation to one's values, beliefs, and goals that testify to the individuality of each person. Perhaps, 
this is the standard of conduct appropriate for a swarm that cooperates perfectly with each other, for example, the termites, but it is not suitable to be a basic principle determining the morality of people's actions. ${ }^{3}$

In the literature, the problem is reduced to two allegations of utilitarianismit does not recognize the special relationships between individuals, and it recognizes the desires that should not be taken into account (Kymlicka, 2009, p. 39). According to the analyzed doctrine, the individual remains in identical moral relations with all people. This assumption seems untrue if one asks a simple question: do I care more about the happiness of my family or the prosperity of the residents in the neighborhood? You do not even have to specify circumstances, which happiness would concern, to understand that such a utilitarian assumption is only methodological fiction. Similarly, we can also reason with regard to the public-legal ground when we make the thesis that there is no obligation to return the loan, if it is possible to spend the amount in a way that would give more utility to the public than just the lender. ${ }^{4}$ The development of this weakness of utilitarianism is the charge that it accepts the unjustified preferences as part of the utility calculation. An appropriate example of such a concept may be a racist society that refuses social assistance to ethnic minorities justifying that such action serves the general increase in the sum of utility. Again, it turns out that when the order to maximize utility is used, there is a moral priority of the interests of the majority of people forming society (Kelly, 2007, p. 50).

In summary, utilitarianism consistently results in the individual's instrumentalization to the welfare of other people. What is special about this is that other doctrines, which give the supreme value of the general good, usually refer to some supra-unit concepts, such as: God, race, national interest. Meanwhile, according to the utilitarians, apart from utility or happiness that characterizes people themselves, neither the state nor society can create these values. That is why the philosophy so perceived in reality objectifies people because it treats them only as carriers of usefulness that strive to produce the largest possible aggregate. In addition, utilitarianism deprived of any additional moral principles can serve as an ideology of any paternalistic or totalitarian state (MacIntyre, 2000, p. 299).

\section{A modernizing attempt to revisit utilitarianism}

The postulate of human equality is permanently inscribed in our civilization. Philosophical attempts to justify this, to some extent, a realistically functioning concept may seem unfounded. However, the role of the scientist is to develop intellec-

\footnotetext{
${ }^{3}$ This task, of course, is in the nature of a pamphlet because one cannot attribute the moral trait to beings who do not have free will and reason, which according to all biological research excludes unfortunate termites from the set of subjects that can be characterized by morality.

${ }^{4}$ Admittedly, there is Hare's position defending utilitarianism, according to which the principle of keeping agreements is such a strong foundation of social order that its breaking would cause more annoyance in the overall utility, but this opinion does not seem convincing (cf. Kymlicka, 2009, p. 59).
} 
tual horizons and find answers not only to questions about the future, but also those relating to the present and the past. By letting myself speculate, I present assumptions that, in my opinion, would allow utilitarian thought to obtain a more stable position in relation to the list of objections raised above.

It seems that the main problem of the presented concept of equality of individuals is the inappropriate application of the principle of maximizing utility in relation to the general public. When a rule explaining the necessity of increasing the sum of pleasure while limiting human suffering, is accepted, it loses its privileged position in relation to the secondary concept of maximizing utility among all people. It is therefore necessary to accept some restrictions that will ensure that no one is victimized by the majority in the name of the general good, that is, the highest utility. This can be achieved thanks to four restrictions on the basic principles of utilitarianism.

First of all: one should refer to one of the basic concepts criticized by the first utilitarians, that is, to the concept of natural human rights, which each individual is entitled to due to being human. Bentham negatively evaluated the theory of the law of nature, describing it as "nonsense on stilts". He claimed there were no rights and obligations outside the legal system that would be in force prior to its creation. ${ }^{5}$ In fact, since utilitarianism itself is conventional, so why not use an additional category created by people that would allow to complement the conceptual mainstream. Bentham argued that it was impossible to create an enumerative, positive catalog of rights that all people would have. Agreeing with this conservative thesis, one can - in the spirit of classical liberalism - use the notion of negative law, and therefore those that do not impose anything, but cannot be violatedthey do not generate moral values, as the utility theory does, but only serve protection of the implementation of this theory (Sheng, 1991, p. 40). Referring to John Locke's doctrine, everyone has the inalienable right to life, liberty and property. Apart from the metaphysical authority from which Locke deduced his argumentation, it must be admitted that the presented catalog sounds convincing enough. It is not extensive, and intuitively anyone could agree with it.

The second proposed solution is the universal legalization of natural law in the form of expressing them in the basic and the highest normative act of the state. They must have the character of an unchanged constitutional norm, because they constitute the rule of law and stability of the system. Thirdly, the principle of equal treatment of individuals should, from a utilitarian perspective, be pursued in the formula of equal care for the well-being of each individual. This guarantees the maintenance of moral equality protected by public law. Finally, fourthly: such a functioning society in order to obtain the greatest usefulness must refer to indirect utilitarianism called rule utilitarianism. As Kymlicka $(2009$, p. 38) wrote:

\footnotetext{
${ }^{5}$ Bentham's aversion to the theory of the law of nature also results from the fact that its political followers were French revolutionaries against whom he was undoubtedly reluctant (more in Rosenblum, 1978, pp. 62-63).
} 
Moral right actions are those that lead to the maximization of utility, but they are more likely when individuals are guided by non-utilitarian rules or habits than when they conduct utilitarian calculations.

This means that the principles of utilitarianism should be guided primarily by public bodies and not individuals in private life.

In conclusion, utilitarianism enriched with the solutions mentioned above could avoid some of its criticisms. It would still be based on the doctrinal elements contained in the concepts of Bentham, Mill, and Spencer. But would it still deserve the name of utilitarianism? This question should be looked for by myself, although I think that each concept, as the world progresses, is naturally forced to adapt to changing conditions or otherwise cease to be professed. It is therefore a necessary contemporary revision of its basic assumptions, allowing it to continue functioning in the $21^{\text {st }}$ century.

\section{References}

Berlin, I. (1969). Four essays of liberty. Oxford: Oxford University Press.

Boaz, D. (2005). Libertarianizm. Poznań: Zysk i S-ka.

Copleston, F. (1989). Historia filozofii (Vol. VIII). Warszawa: Instytut Wydawniczy PAX.

Górecki, O. (2010). Korelacja etyki z gospodarką w etyce Herberta Spencera. Annales. Ethics in Economic Life, 13(2), 59-69.

Gray, J. (1994). Liberalizm. Kraków: Społeczny Instytut Wydawniczy Znak.

Häyry, M. (1994). Liberal utilitarianism and applied ethics. London: Routledge Press.

Hofstadter, R. (1945). Social Darwinism in American thought 1860-1915. Philadelphia: University of Pennsylvania Press.

Hołówka, J. (1995). Wstęp. In J. S. Mill, O rządzie reprezentatywnym. Kraków: Społeczny Instytut Wydawniczy Znak.

Hudzik, J. P., (2002). Wykłady z filozofii polityki, Lublin: Wydawnictwo Uniwersytetu Marii Curie-Skłodowskiej.

Kasprzyk, L. (1961). Idee społeczno-polityczne Herberta Spencera. Kraków: Stenotypia.

Kasprzyk, L. (1967). Spencer. Warszawa: Wydawnictwo Wiedza Powszechna.

Kelly, P. (2007). Liberalizm. Warszawa: Wydawnictwo Sic!

Kowalczyk, S. (1995). Liberalizm i jego filozofia. Katowice: Wydawnictwo Unia.

Król, M. (2008). Filozofia polityczna. Kraków: Znak.

Kwaśnicki, W. (2000). Historia myśli liberalnej. Warszawa: Polskie Wydawnictwo Ekonomiczne.

Kymlicka, W. (2009). Wspótczesna filozofia polityczna. Warszawa: Aletheia.

Ludwikowski, R., \& Woleński, J. (1979). J.S. Mill. Warszawa: Wydawnictwo Wiedza Powszechna.

MacIntyre, A. (2000). Krótka historia etyki. Warszawa: Wydawnictwo Naukowe PWN. 
Mill, J. S. (1995). O rządzie reprezentatywnym. Kraków: Społeczny Instytut Wydawniczy Znak.

Mill, J. S. (2005). Utylitaryzm. O wolności. Warszawa: Wydawnictwo Naukowe PWN.

Quinton, A. (1989). Utilitarian ethics. London: Gerald Duckworth.

Rau, Z. (2000). Liberalizm. Zarys myśli politycznej XIX i XX w. Warszawa: Aletheia.

Rau, Z. (2008). Zapomniana wolność. W poszukiwaniu historycznych podstaw liberalizmu. Warszawa: Wydawnictwo Naukowe Scholar.

Rosenblum, N. L. (1978). Bentham' theory of the modern state. Cambridge: Harvard University Press.

Sheng, C. L. (1991). A new approach to utilitarianism. A unified utilitarian theory and its application to distributive justice. London: Kluwer Academic Publishers.

Sheng, C. L. (1998). A utilitarian general theory of value (Value Inquiry Book Series, Vol. 61). Amsterdam: Brill Rodopi.

Spencer, H. (1851). Social statics, or the conditions essential to human happiness specified, and the first of them developed. London: John Chapman.

Spencer, H. (2002). Jednostka wobec państwa. Warszawa: Liber.

Szahaj, A., \& Jakubowski, M. N. (2005). Filozofia polityki. Warszawa: Wydawnictwo Naukowe PWN.

Środa, M. (2003). Indywidualizm i jego krytycy. Warszawa: Aletheia.

Taylor, M. W. (2000). Men versus the state. Herbert Spencer and late Victorian individualism. Oxford: Clarendon Press.

Tulejski, T. (2004). Od zasady użyteczności do demokracji. Filozofia polityczna Jeremy Benthama. Łódź: Wydawnictwo Uniwersytetu Łódzkiego.

Vardy, P., \& Grosch P. (1995). Etyka. Poglady i problemy. Poznań: Zysk i S-ka.

White, S. (2008). Równość. Warszawa: Sic!

Wroczyński, R. (2002). Wstęp. In H. Spencer, O wychowaniu umysłowym, moralnym i fizycznym. Warszawa: Wydawnictwo Akademickie Żak. 